\title{
Achalasia: Treatment options revisited
}

\author{
Willemijntje A Hoogerwerf MD, Pankaj J Pasricha MD
}

\begin{abstract}
WA Hoogerwerf, PJ Pasricha. Achalasia: Treatment options revisited. Can J Gastroenterol 2000;14(5):406-409. The aim of all current forms of treatment of achalasia is to enable the patient to eat without disabling symptoms such as dysphagia, regurgitation, coughing or choking. Historically, this has been accomplished by mechanical disruption of the lower esophageal sphincter fibres, either by means of pneumatic dilation (PD) or by open surgical myotomy. The addition of laparoscopic myotomy and botulinum toxin (BTX) injection to the therapeutic armamentarium has triggered a recent series of reviews to determine the optimal therapeutic approach. Both PD and BTX have excellent short term (less than three months) efficacy in the majority of patients. New data have been published that suggest that PD and BTX (with repeat injections) can potentially obtain long term efficacy. PD is still considered the first-line treatment by most physicians; its main disadvantage is risk of perforation. BTX injection is evolving as an excellent, safe option for patients who are considered high risk for more invasive procedures. Laparoscopic myotomy with combined antireflux surgery is an increasingly attractive option in younger patients with achalasia, but long term follow-up studies are required to establish its efficacy and the potential for reflux-related sequelae.
\end{abstract}

Key Words: Achalasia; Botulinum toxin; Pneumatic dilation

\section{Achalasie : revue des différents traitements possibles}

RÉSUMÉ : Les différentes formes de traitement de l'achalasie ont toutes pour but de permettre aux patients de manger sans éprouver de symptômes invalidants comme la dysphagie, les régurgitations, la toux et la suffocation. Pour ce faire, on procédait, autrefois, à la rupture mécanique des fibres du sphincter inférieur de l'œsophage, soit par dilatation pneumatique (DP), soit par myotomie chirurgicale à ciel ouvert. Se sont ajoutées à ces deux méthodes la myotomie par laparoscopie et l'injection de toxine botulinique (TB), ce qui a suscité une série d'examens récents visant à déterminer le meilleur traitement possible. La DP et la TB donnent d'excellents résultats à court terme (moins de trois mois) dans la plupart des cas. Selon de nouvelles données, la DP et les injections répétées de TB pourraient s'avérer efficaces à long terme. La DP est toujours considérée comme le traitement de première intention par la grande majorité des médecins, mais elle comporte un risque de perforation. Quant aux injections de TB, elles se présentent de plus en plus comme une solution valable, sûre, pour les patients jugés mauvais candidats à un traitement plus effractif. La myotomie par laparoscopie, associée à une intervention chirurgicale antireflux, gagne du terrain, surtout chez les jeunes patients, mais il est nécessaire de mener des études de suivi à long terme pour déterminer l'efficacité du traitement et le risque de séquelles possibles liées au reflux.
A chalasia was one of the first gastrointestinal motility disorders to be characterized, both clinically and manometrically. Failure of relaxation of the lower esophageal sphincter (LES) is the cardinal feature of this disease, thought to result from a relatively selective degeneration of the inhibitory neurons in the surrounding myenteric plexus (Figure 1) (1-3). This leads to a functional obstruction of the esophagus that, along with aperistalsis in the body of the esophagus, is responsible for the major symptoms of achalasia: dysphagia for solids and liquids, regurgitation of undigested food and chest pain. All current methods of treatment are essentially palliative in nature and are focused on reducing the LES pressure. The main focus of this review will be on the use of botulinum toxin (BTX) for this condition and how it compares with other available therapies.

\section{BTX}

BTX blocks the calcium-dependent release of acetylcholine from presynaptic cholinergic nerve terminals. It is a neurotoxin produced by Clostridium botulinum. Although several

This mini-review was prepared from a presentation made at the 1998 World Congress of Gastroenterology, September 6 to 11, 1998, Vienna, Austria The University of Texas Medical Branch at Galveston, Department of Internal Medicine, Division of Gastroenterology, Galveston, Texas

Correspondence and reprints: Dr Pankaj J Pasricha, University of Texas Medical Branch, Division of Gastroenterology, 4.106 McCullough

Building, 301 University Boulevard, Galveston, Texas 77555-0764 USA. Telephone 409-772-5615, fax 409-772-4789, e-mail

jpasrich@utmb.edu

Received for publication May 10, 1999. Accepted May 14, 1999 
serotypes are known, the one used clinically is BTX type A. Pasricha et al (4) were the first to demonstrate the application of BTX for the treatment of achalasia in a doubleblind, randomized, placebo controlled study. Since then, multiple studies and several reviews have been published (4-23). BTX causes a significant reduction in resting baseline LES pressure, esophageal clearance and symptoms (Figure 2). The efficacy ranges from $65 \%$ to $90 \%$ after a single injection, with the effect lasting anywhere from three months to more than one year. The main limitation to the use of BTX for achalasia is its lack of significant long term results with a single injection. With repeat injections at an average of every 10 months, Annese et al (20) recently reported the highest long term efficacy rate to date ( $75 \%$ after a mean follow-up of $24 \pm 15$ months).

Approximately 80 to $100 \mathrm{U}$ of BTX are injected endoscopically into the LES in four aliquots of $1.0 \mathrm{~mL}$ in each quadrant. Preliminary reports have thus far not shown a significant difference in efficacy with higher doses of BTX $(17,18)$; more precise localization of the LES with the use of endoscopic ultrasound or injections over a wider area of the LES are similarly unproven in their effects on efficacy $(20,21)$.

Injection of BTX appears to be safe. The most commonly reported complications are periprocedural transient chest pain and heartburn. Esophageal wall injury and paraesophageal tissue inflammation have been reported in two patients (22). Caution needs to be exercised with regard to potential, yet unknown, late side effects. Antibodies may develop against the toxin, causing resistance.

Given its low risk procedural profile, BTX injection is an attractive therapeutic option for high risk surgical patients and elderly patients, in whom conservative, albeit temporizing, management is preferred.

\section{DRUG THERAPY}

Nitrates and calcium channel antagonists have been recommended for treatment of achalasia. The rationale behind the use of these medications is their potential to decrease LES tone by relaxing gastrointestinal smooth muscle. However, the limitations in the use of these drugs are several: they are short acting; they can have significant side effects such as headaches, hypotension and tachyphylaxis; and, although a decrease in LES pressure has been well documented by manometry, symptom improvement has varied greatly among different studies $(24,25)$. In general, most patients tend to opt for other, more satisfactory forms of treatment after they have been on these drugs for a few months.

\section{PNEUMATIC BALLOON DILATION}

Pneumatic balloon dilation has traditionally been considered the standard, first-line treatment for achalasia. Although the tools for dilation have become more sophisticated (Sir Thomas Willis treated his patient in 1672 by using a whale bone), the principle of therapy has changed little over the centuries. Multiple studies have been published on pneumatic dilation (PD) for achalasia, using different dilators (the older Mosher bag, Sippy dilators, Brown-McHardy, Rider-
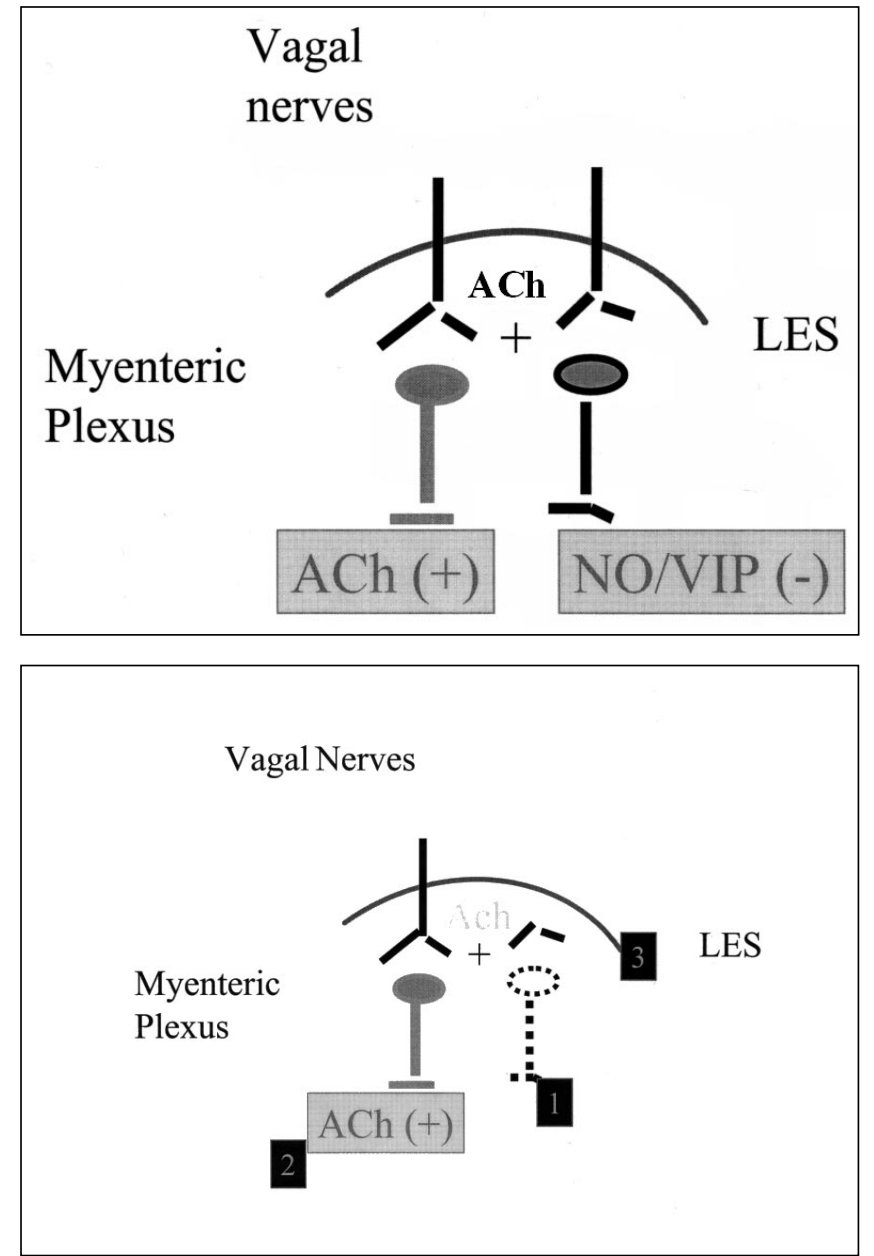

Figure 1) Lower esophageal sphincter (LES) regulation. Top Normal LES pressure can be viewed as a balance between the contractile effects of acetylcholine $(\mathrm{ACh})$ and the relaxing effects of the neurotransmitters nitric oxide (NO) and vasoactive intestinal peptide (VIP) in the myenteric plexus. Bottom In achalasia, there is a selective loss of nitrinergic neurons in the myenteric plexus (1). This leads to an unopposed excitation of the LES by ACh (2), resulting in a hypertonic LES that fails to relax upon swallowing (3)

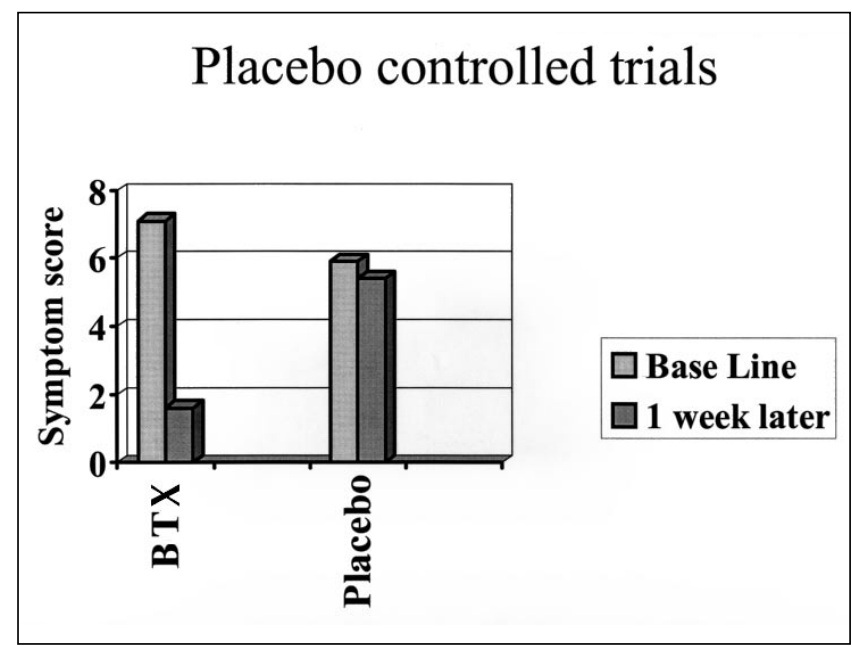

Figure 2) Symptomatic improvement after botulinum toxin (BTX) injection. There is a statistically significant improvement in symptom score one week after BTX injection as compared to placebo. Data from reference 5 
TABLE 1

\begin{tabular}{|c|c|c|c|c|}
\hline Author & $\begin{array}{c}\text { Number of } \\
\text { patients (PD } \\
\text { versus BTX) }\end{array}$ & $\begin{array}{c}\text { Initial } \\
\text { treatment } \\
\text { failure (PD } \\
\text { versus BTX) }\end{array}$ & $\begin{array}{c}\text { Efficacy } \\
\text { (one month) }\end{array}$ & $\begin{array}{c}\text { Efficacy } \\
\text { (one year) }\end{array}$ \\
\hline $\begin{array}{l}\text { Schroeder et al } \\
\text { (15) }\end{array}$ & 9 versus 11 & $=( \pm 35 \%)$ & $=$ & \\
\hline $\begin{array}{c}\text { Bansal et al } \\
\text { (16) }\end{array}$ & 9 versus 12 & $=( \pm 13 \%)$ & & $=$ \\
\hline $\begin{array}{l}\text { Vaezi et al } \\
\text { (19) }\end{array}$ & 20 versus 22 & $=$ & & $\mathrm{PD}>\mathrm{BTX}$ \\
\hline
\end{tabular}

Moeller dilators, and the now commonly used Rigiflex balloon) and techniques, varying with regard to balloon distention times, balloon pressure, balloon diameter, and rate and number of inflations. A review of the literature by Vaezi and Richter (6) concluded that about two-thirds of the patients have good to excellent symptom improvement after one or more dilations over a mean time of 4.6 years for the older dilators and 1.0 year for the newer dilators. The major drawback of this procedure is the low but significant risk of esophageal perforation, averaging about $5 \%$.

Interpretation of the results of PD is limited by the lack of good prospective studies. Data from one of the few studies of this kind give five-year remission rates of only about $26 \%$ from a single dilation, with most patients requiring two or more dilations over a five-year period (26). Retrospective analyses portray a more optimistic outcome, however, with remission rates averaging around $70 \%$ or higher (27).

\section{SURGICAL MYOTOMY}

Surgery has been considered the most permanent form of treatment for achalasia. Significant disadvantages include the need for hospitalization and surgical morbidity. The short term efficacy after surgical myotomy is $80 \%$ to $90 \%$. However, late relapse, which is felt to occur in part due to longstanding postsurgical gastroesophageal reflux disease, occurs in up to one-third of the patients $(28,29)$. Whether to perform an antireflux procedure at the time of myotomy remains controversial but is generally recommended for abdominal approaches. With the introduction of laparoscopic or thoracoscopic myotomy, surgical intervention has become a more attractive form of therapy (shorter hospital stay and recovery time) $(30,31)$. Short term outcome appears equivalent to open surgical myotomy. However, the long term consequences, especially as related to reflux, are expected to remain problematic.

\section{COMPARATIVE STUDIES}

Despite the abundance of literature on management of achalasia, there appears to be a relative paucity of prospective, randomized controlled studies that directly compare different treatment modalities. Until recently, there have only been two really effective methods of treating patients with achalasia: forceful dilation and surgery. Data from uncon- trolled retrospective trials have, in general, suggested that success rates were higher after surgery. In a prospective, randomized, controlled trial comparing PD (using a Mosher bag) with surgical anterior esophagomyotomy, Csendes et al (32) demonstrated a five-year response rate of $65 \%$ versus $95 \%$ in clear favour of surgery.

The common limitation of PD and BTX injection is the lack of long term efficacy, with the need for repeat intervention. The literature has tried to compare the efficacy of one technique with the other. The definition of long term and short term efficacy appears arbitrary because it varies between authors. While some will define one-year follow-up data as short term, others will define a similar time span as long term. Annese et al (8) were the first to publish a randomized, controlled, double-blind study comparing BTX with placebo injections and with PD of treatment failures. One or two BTX injections appeared as effective as PD in short term relief of dysphagia. However, $87 \%$ (seven of eight) of the patients required a second injection within one year of the first injection (8). Studies published in abstract form comparing BTX with PD in a prospective, randomized manner are summarized in Table 1. Preliminary data from Bansal et al (16) suggested that the 'short term efficacy' (less than 12 months) of PD and BTX injections are equivalent, but initial treatment failure was significantly higher with BTX (six of 12 patients). On the contrary, Vaezi et al (19) found a significantly higher "long term" efficacy (less than 12 months) with PD compared with BTX. Initial treatment failures, however, were similar for both treatment modalities in this study. Although reviews and meta-analyses clearly suggest a longer lasting effect from a single dilation than from a single BTX injection, a recent study by Prakash et al (23) using survival analysis suggested that BTX injections given as needed have an efficacy similar to a single PD within the first two years of injection. In addition, retreatment with BTX injections may delay the need for subsequent injections.

A major problem in comparative studies is the relative rarity of the disease and the difficulty in maintaining long term follow-up in patients over a five- to 10 -year period. The Csendes et al (32) trial took about 15 years to complete and is unlikely to be reproduced. The debate should perhaps now be refocused, not only on efficacy of treatment regimens, but on issues of cost effectiveness and quality of life. As an example, it has been estimated that the long term (seven years) cumulative costs of surgery (approximately $\$ 20,000$ ) are nearly two-and-a-half times more than those of PD, even taking into account the perforation rate and need for retreatment (33). A preliminary cost analysis of BTX injection, PD and laparoscopic Heller myotomy with fundoplication using decision analysis found PD to be the 'least costly initial strategy' (34).

\section{CONCLUSIONS AND RECOMMENDATIONS}

It should be clear from this brief review that the final word on treatment of achalasia is far from being written. Despite some recent advances, therapy remains palliative and each method has a significant drawback. Nevertheless, most patients can 
expect to gain good to excellent symptomatic relief of their obstructive symptoms and improvement in their quality of life. With the variety of options available, it is now increasingly possible to tailor the treatment to the needs of the patient. Thus, most young patients, desirous of a single permanent treatment, may be offered a laparascopic myotomy with the caveat that they should be prepared for long term reflux monitoring and treatment. Others may opt for PD with good expectations from one or two dilations in the first five years. Patients fearful of perforation or those felt to be at high risk for more aggressive therapy may be given a choice of BTX injection, with the understanding that repeat injections will be required periodically.

\section{REFERENCES}

1. Goldblum JR, Whyte RI, Orringer MB, Appelman HD. Achalasia. A morphologic study of 42 resected specimens. Am J Surg Pathol 1994;18:327-37.

2. Aggestrup S, Uddman R, Sundler F, et al. Lack of vasoactive intestinal polypeptide nerves in esophageal achalasia. Gastroenterology 1983;84:924-7.

3. Mearin F, Mourelle M, Guarner F, et al. Patients with achalasia lack nitric oxide synthase in the gastro-oesophageal junction. Eur J Clin Invest 1993;23:724-8.

4. Pasricha PJ, Ravich WJ, Hendrix TR, Sostre S, Jones B, Kalloo AN. Intrasphincteric botulinum toxin for the treatment of achalasia. N Engl J Med 1995;332:774-8. Erratum in N Engl J Med 1995,333:75.

5. Pasricha PJ, Rai R, Ravich WJ, Hendrix TR, Kalloo AN. Botulinum toxin for achalasia: Long-term outcome and predictors of response. Gastroenterology 1996;110:1410-5.

6. Vaezi MF, Richter JE. Current therapies for achalasia: Comparison and efficacy. J Clin Gastroenterol 1998;27:21-35.

7. Spiess AE, Kahrilas PJ. Treating achalasia: from whalebone to laparoscope. JAMA 1998;280:638-42.

8. Annese V, Basciani M, Perri F, et al. Controlled trial of botulinum toxin injection versus placebo and pneumatic dilation in achalasia. Gastroenterology 1996;111:1418-24.

9. Annese V, D'Onofrio V, Andriulli A. Botulinum toxin in long-term therapy for achalasia. Ann Intern Med 1998;128:696.

10. Cuillière $\mathrm{C}$, Ducrotte $\mathrm{P}$, Zerbib F, et al. Achalasia: outcome of patients treated with intrasphincteric injection of botulinum toxin. Gut 1997;41:87-92.

11. Rollan A, Gonzalez R, Carvajal S, Chianale J. Endoscopic intrasphincteric injection of botulinum toxin for the treatment of achalasia. J Clin Gastroenterol 1995;20:189-91.

12. Fishman VM, Parkman HP, Schiano TD, et al. Symptomatic improvement in achalasia after botulinum toxin injection of the lower esophageal sphincter. Am J Gastroenterol 1996;91:1724-30.

13. Gordon JM, Eaker EY. Prospective study of esophageal botulinum toxin injection in high-risk achalasia patients. Am J Gastroenterol 1997;92:1812-7.

14. Annese V, Basciani M, Lombardi G, et al. Perendoscopic injection of botulinum toxin is effective in achalasia after failure of myotomy or pneumatic dilation. Gastrointest Endosc 1996;44:461-5.

15. Schroeder P, Slaughter R, Turbey C, Morgan D, Kohler R, Richter J. Treatment of achalasia: A botulinum toxin versus pneumatic dilatation. Am J Gastroenterol 1995;90:1571. (Abst)
16. Bansal R, Koshy S, Sheiman JM, Barnette JL, Nostrant TT. A randomized trial of Witzel pneumatic dilatation versus intrasphincteric injection of botulinum toxin for achalasia. Gastroenterology 1995;110:A56. (Abst)

17. Annese V, Bassotti G, Coccia G, et al. Multicentre, dose-finding study of botulinum toxin for the therapy of esophageal achalasia. Gastroenterology 1998;114:G2949.

18. Kozarek RA, Gelfand MD, Patterson DJ, et al. Randomized prospective trial of 50 vs 100 IU Botox for achalasia - long term follow-up. Gastroenterology 1997;112:A184. (Abst)

19. Vaezi M, Richter JE, Wilcox M, Schroeder P, Slaughter R. One-year follow-up: pneumatic dilatation more effective than botulinum toxin. Gastroenterology 1997;112:A318. (Abst)

20. Annese V, Basciani M, Borrelli O, Leandro G, Simone P, Andriulli A. Intrasphincteric injection of botulinum toxin is effective in long-term treatment of esophageal achalasia. Muscle Nerve 1998;21:1540-2.

21. Hoffman BJ, Knapple WL, Bhutani MS, Verne GN, Hawes RH. Treatment of achalasia by injection of botulinum toxin under endoscopic ultrasound guidance. Gastrointest Endosc 1997;45:77-9.

22. Eaker EY, Gordon JM, Vogel SB. Untoward effects of esophageal botulinum toxin injection in the treatment of achalasia. Dig Dis Sci 1997;42:724-7.

23. Prakash C, Freedland KE, Chan MF, Clouse RE. Botulinum toxin injections for achalasia symptoms can approximate the short term efficacy of a single pneumatic dilation: A survival analysis approach. Am J Gastroenterol 1999;94:328-33.

24. Short TP, Thomas E. An overview of the role of calcium antagonists in the treatment of achalasia and diffuse oesophageal spasm. Drugs 1992;43:177-84.

25. Traube M, Dubovik S, Lange RC, McCallum RW. The role of nifedipine therapy in achalasia: results of a randomized, double-blind, placebo-controlled study. Am J Gastroenterol 1989;84:1259-62.

26. Eckardt VF, Aignherr C, Bernhard G. Predictors of outcome in patients with achalasia treated by pneumatic dilation. Gastroenterology 1992;103:1732-8.

27. Katz PO, Gilbert J, Castell DO. Pneumatic dilatation is effective long-term treatment for achalasia. Dig Dis Sci 1998;43:1973-7.

28. Malthaner RA, Todd TR, Miller L, Pearson FG. Long-term results in surgically managed esophageal achalasia. Ann Thorac Surg 1994;58:1343-7.

29. Ellis FH Jr, Watkins E Jr, Gibb SP, Heatley GJ. Ten to 20-year clinical results after short esophagomyotomy without an antireflux procedure (modified Heller operation) for esophageal achalasia. Eur J Cardiothorac Surg 1992;6:86-90.

30. Vogt D, Curet M, Pitcher D, Josloff R, Milne RL, Zucker K. Successful treatment of esophageal achalasia with laparoscopic Heller myotomy and Toupet fundoplication. Am J Surg 1997;174:709-14.

31. Ancona E, Anselmino M, Zaninotto G, et al. Esophageal achalasia: Laparoscopic versus conventional open Heller-Dor operation. Am J Surg 1995;170:265-70.

32. Csendes A, Braghetto I, Henriquez A, Cortes C. Late results of a prospective randomised study comparing forceful dilatation and oesophagomyotomy in patients with achalasia. Gut 1989;30:299-304.

33. Parkman HP, Reynolds JC, Ouyang A, Rosato EF, Eisenberg JM, Cohen S. Pneumatic dilatation or esophagomyotomy treatment for idiopathic achalasia: clinical outcomes and cost analysis. Dig Dis Sci 1993;38:75-85.

34. Imperiale TF, O'Connor JB, Vaezi MF, Richter JE. A cost-analysis of alternative treatment strategies for achalasia. Gastroenterology 1998;114:G0076. (Abst) 


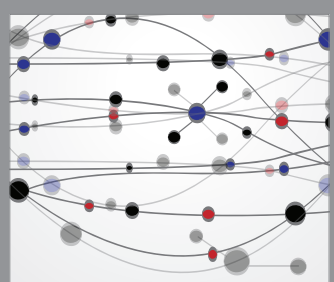

The Scientific World Journal
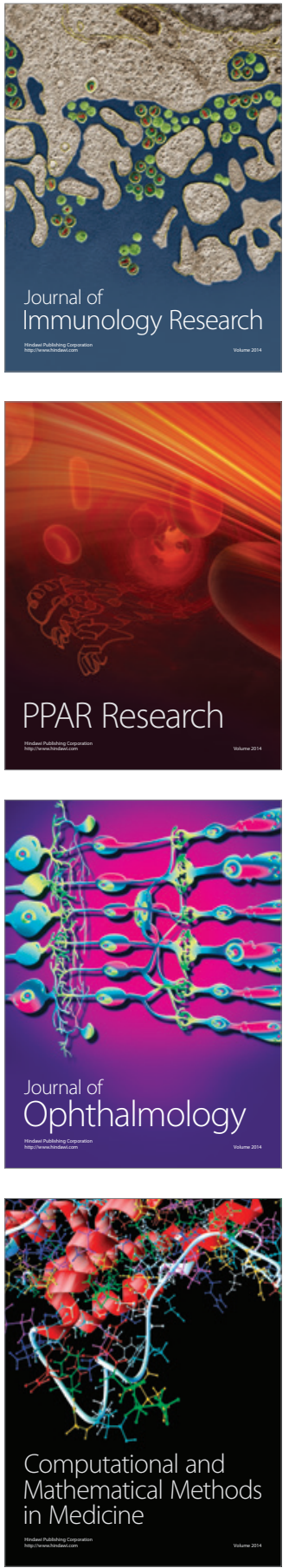

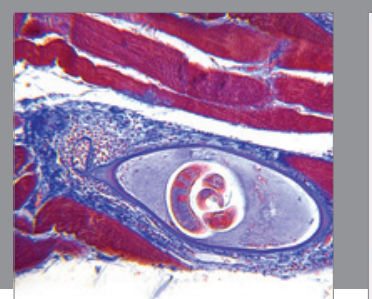

Gastroenterology Research and Practice

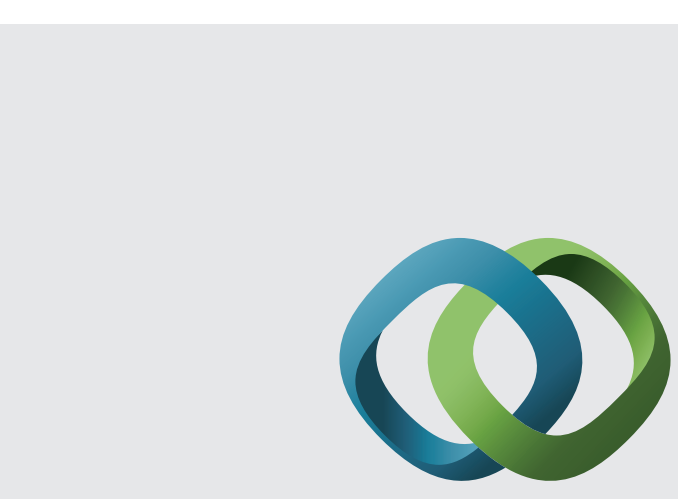

\section{Hindawi}

Submit your manuscripts at

http://www.hindawi.com
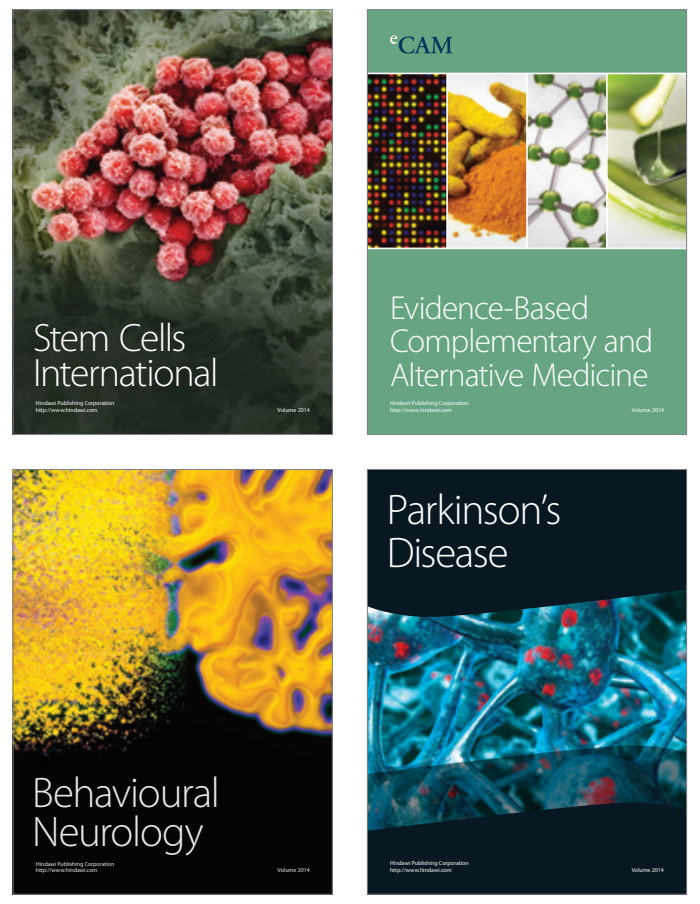
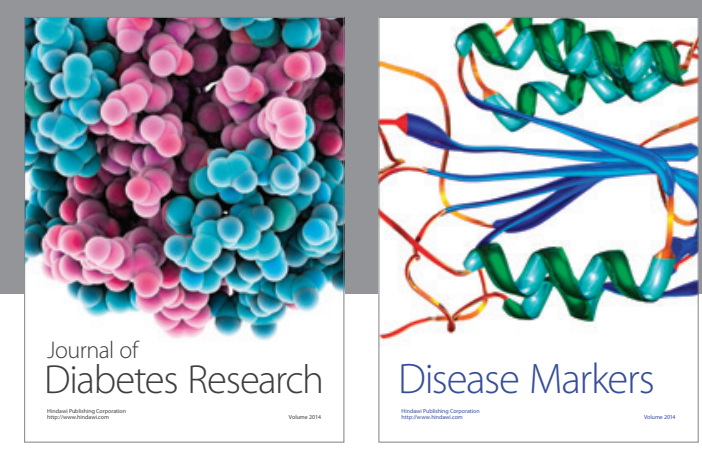

Disease Markers
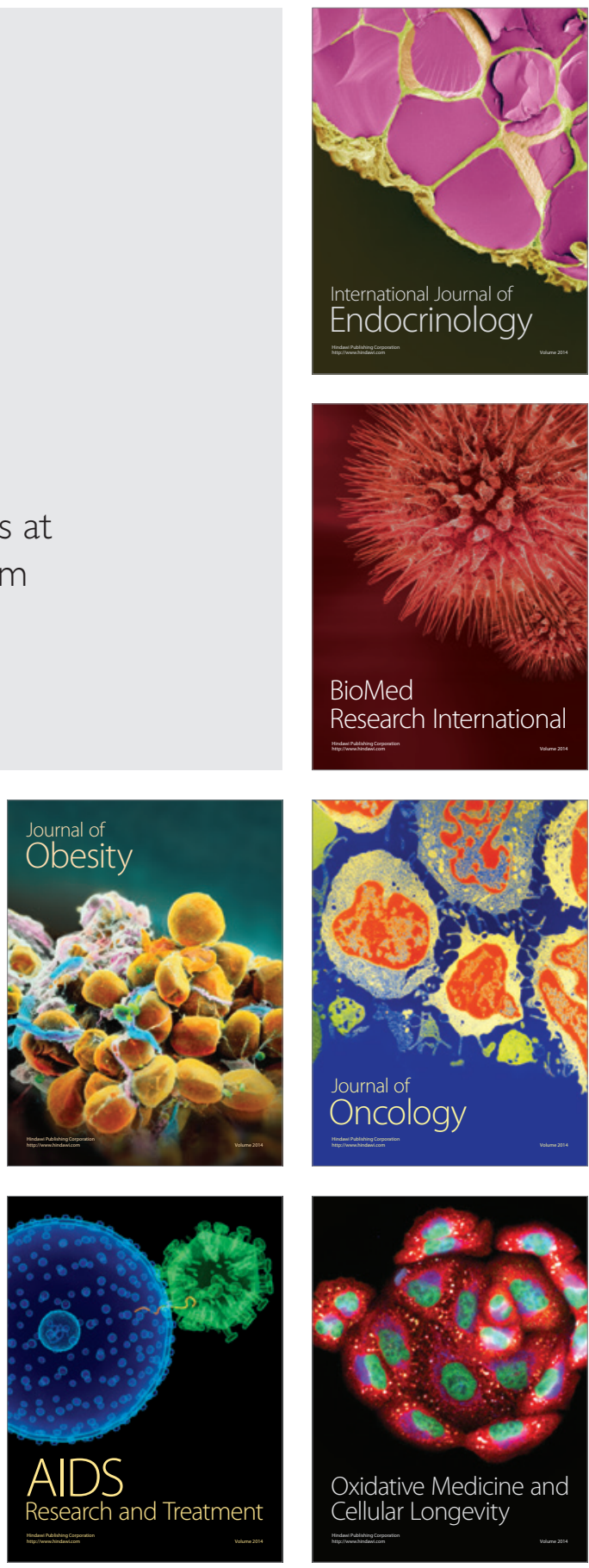